\title{
ENKELE TREKKE UIT DIE VROOMHEID VAN JODOCUS VAN LODENSTEIN.
}

By die lees van die geskrifte van die Utrechtse predikant Jodocus van Lodenstein, kom die gedagte steeds na vore dat sy denkbeelde tot in 'n groot mate verteenwoordigend genoem kan word van die Piëtistiese beweging wat gedurende die middel van die sewentiende eeu in Nederland opgekom en gebloei het. Die nadere bepaling en stilstaan by enkele trekke uit die vroomheid van Lodenstein sal dan ook kan help om die Nederlandse Piëtisme van daardie dae beter te verstaan.

By Lodenstein leef die gedagte van die onmiddelike en persoonlike konfrontasie met God ') en hy sien God as 'n absoluut soewereine Wese. God is vir hom die .Van-sig-selfheyd . . . eene Ongeschapene, onafhangelyk van sijnene Wille in alle Saken, in sig selve ten hoogsten, volmaakt, vergenoegd, Geluksalig, van niemand bepaald, beraden, geholpen, niets buyten sig begeerende, selfs-volkomentlyk, Willen, wille en 't Gewilde zynde."2) Hierdie onbeperkte soewereiniteit van

1) Trimp, J. C., Joost van Lodenstein als Piëtistisch Dichter, Groningen, 1953, bl. 111.

2) J. J. VAN LODENSTEIN, Geestelyke Gedagten, Amsterdam, 1729, bl. 3. 
God wek by Lodenstein die huiwering vir die Goddelike, waarteenoor hy as skepsel alleen maar nietig is.

En Wie
Wie ben ik Worm/of Maad
(Zeg ik) die uwen Raad/
't Geheim van uw Gena-verbond/
Zoud peylen tot de Grond? ${ }^{3}$ )

Tog wek hierdie gevoel van afstand tussen God en mens geen vrees by Lodenstein nie, want hy besef daarteenoor, die verbondenheid van God met die mens, en hierdie besef van verbondenheid domineer eintlik veel meer sy denke. Die gedagte van die verbondenheid van God met die mens lei daartoe dat hy met vertroue die Oneindige God sien as dié groot steunpilaar van die onvolkome mens.) Sterk kom juis hierdie gedagtes na vore in die liedere wat hy skryf tydens sy ballingskap te Fort Nieuw Rees. Volgens van Ryp ${ }^{3}$ ) was die gedagte van die „onbepaalde souvereiniteit van den Gods des Hemels" 'n belangrike element in die denke van Lodenstein. Tog kan mens hierdie uitspraak van VAN RYP maar met reserwe aanvaar, want by die lees van die werke van Lodenstein kan mens nie aan die gedagte ontkom dat die immanensie en die nabyheid van God veel meer kleur vir Lodenstein het as die afstand tussen God en mens.

Daarom, miskien, gee Lodenstein meer aandag aan Jesus Christus, die Seun van God. In sy uiteensetting van die taak en doel waarmee Gods Seun op aarde verskyn het, blyk alreeds dat Lodenstein se hele vroomheid gedomineer word deur die eis tot heiligmaking.

$\mathrm{Nu}$ zal ik 't dierbaar Kruys voor eeuwig dankbaar zijn/

Dat door zijn vloek my vrijd voor eeuwig schand en pijn

Maar meest dat ik daardoor vans Vleesches lust en vry

Ben aan de Wereld gekruyst. ${ }^{6}$ )

Op hierdie manier kan Lodenstein Jesus nie net sien as die versoenende Middelaar nie, maar juis as die groot voorbeeld van die mens wat op weg is na die heiligmaking. ${ }^{7}$ ) Dan kan Lodenstein self sê dat die rede waarom Jesus op aarde gekom het alleen was om die Goddelike eis van die heiligmaking te bevestig. ${ }^{8}$ ) So blyk reeds by Lodenstein se denke oor Jesus, die eensydigheid ${ }^{9}$ ) wat sy hele religieuse denke en vroomheid oorheers.

3) J. VAN LODENSTEIN, Uytspanningen, Amsterdam, 1752, bl. 76.

4) Uytspanningen, bl. 78.

5) H. VAN RYP, Zions Weeklagen, Amsterdam, 1729, bl. 10.

6) Uytspanningen, bl. 103.

7) Uytspanningen, bl. 155.

8) J. VAN LODENSTEIN, Beschouwinge van Zion, Amsterdam, 1729, bl. 53.

9) Beschouwinge van Zion, bl. 148. 
Die Heilige Gees, wat uitgaan van die Vader en die Seun, is vir Lodenstein God wat in die mens inwoon. ${ }^{10}$ ) Lodenstein onderskei die Heilige Gees nie baie skerp van die Vader en veral nie van Jesus nie. ${ }^{11}$ ) Hy spreek van 'n vereniging van Jesus met die mens en 'n inwoning van die Heilige Gees ${ }^{12}$ ) en alhoewel beide strek tot die heiligmaking van die mens, ${ }^{13}$ ) is dit tog nie presies dieselfde nie. Lodenstein se vroomheid sirkel veel meer om die persoon en werk van Christus, alhoewel sy beskouing van God tog wel trinitaries is.

'n Karakteristieke trek van Lodenstein se beskouing van God is sy beklemtoning van die theokratiese. Veral in sy liedere op die gebeurtenisse van nasionale belang kom dit uit dat hy teenslag en sukses byna uitsluitlik toeskryf aan Gods toorn of guns. ${ }^{14}$ ) So skryf Lodenstein aan die slot van sy vers "De Medicijn-meester Duc d'Alba": „De Heere Godt heeft ons door d'uytkomst geleerd dat ' $t$ jaar 1672 daar toe bestemd en de Francoysen daar toe verkooren waren, die ' $t$ op die tijd tot zo verre hebben uytgevoerd. Dog nog en is de waare genezinge van Zion niet gerezen." ${ }^{15}$ )

Teenoor die algenoegsame, drieënige God staan die mens op hierdie wêreld. 'n Mens wat van nature verdorwe is en geneig tot die kwaad ,door welke hy dood in de zonden, onmagtig is yts te doen van sig selven." ${ }^{16}$ ) Dat hierdie mening egter ook nie absoluut is vir Lodenstein nie, blyk uit die feit dat hy die sondige mens nie as volkome onmagtig in sy staat van sonde sien nie. ${ }^{17}$ ) Die sonde van die mens, wat die mens laat verval het in die staat van verdorwenheid, is die afkering van die mens van God om in die eie die heil te vind. ${ }^{18}$ ) In plaas dat die geskape mens hom wil stel as afhanklike onder die Skepper, wil hy onafhanklik wees. Lodenstein noem dit dan ook een van die "Hoofdquaaden" van die mens. ${ }^{19}$ ) Tog het die sondige mens op die aarde nog 'n taak, naamlik om God te ken met verstand en wil en om Hom lief te hê en in ewigheid te loof en te prys. ${ }^{20}$ ) Hierdie omskrywing van die taak van die mens op aarde wys alreeds in die rigting van die inrerlik-affektiewe trek wat die vroomheid van Lodenstein vertoon.

10) Beschouwinge van Zion, bl. 240: Daar leert men dat de Allerheiligste Dry-eenheid woonen komt in den Geloovige en dat dees werd een Tempel van de $\mathrm{H}$. Godheyd, die waarlijk daar in woont, leeft.

11) Uytspanningen, bl. 98.

12) Vergelyk Beschouwinge van Zion, bl. 168.

13) Beschouwinge van Zion, bl. 166.

14) Vergelyk Uytspanningen, bl. 319 asook P. JZN. Proost, Jodocus van Lodenstein, Amsterdam, 1880. bl. 26.

15) Uytspanningen, bl. 385.

16) Geestelyke Gedagten, bl. 307.

17) Geestelyke Gedagten, bl. 294: dat Schepsel is van Jehova daartoe geschapen ... dat het met zyn verstand, God en alle desselfs Eygenschappen kennen zoude ...

18) Geestelyke Gedagten, bl. 321.

19) Beschouwinge van Zion, bl. 51.

20) Geestelyke Gedagten, bl. 294. 
Die mens as sondige en afvallige wese het egter die vergewing van sonde en die versoening deur Jesus Christus nodig om op aarde te kom tot die heiligmaking en die saligheid in die hiernamaals. Die mens moet dus die ..verdienste" van Christus in die geloof aanvaar, wil die mens werklik daartoe kom. Die aanvaar in die geloof beteken vir Lodenstein die volledige ondergeskikmaak van die eie wil aan die wil van God. Die terugkeer tot die koninkryk van God beteken vir die mens in die eerste plek die volledige gehoorsaamheid. Maar dié gehoorsaamheid kan die mens alleen bereik omdat Jesus deur sy lyding en dood die versoening tussen mens en God tot stand gebring het. Omdat Christus gely en gesterwe het, daarom kan die mens nou die vergewing van sonde en die regverdiging uit genade ontvang. ${ }^{21}$ ) Opvallend is egter die standpunt van Lodenstein wat die regverdiging en die vergewing van die sondes minder belangrik ag as die heiligmaking. ${ }^{22}$ ) Wat vir LuTHER en CALvyN sentraal staan in die Evangelie, word deur Lodenstein nie meer so gesien nie. ,Ende dat dat groot of grootste werk (t.w. die lyding) speciaal op de vergevinge der zonden zijn opsigt heeft/segt wel/dat gemelde vergevinge een nader eynde en eygen effect is van dat zelve/maar niet 't opperst eynde: want gy weet wel dat hoe een eynde verder is/hoe hooger en meer de sake is die be-oogd werd. Nu geef ons 't Heilig Woord duydelijk te kennen/dat alle die dingen/zo Betalinge als Vergevinge, zijn om de Heyligmakinge als een verder of hooger eynde." ${ }^{23}$ ) So gesien is die regverdiging maar net 'n poort waar die sondaar deur moet gaan om tot die heiligmaking te kom. ${ }^{24}$ )

Die geloof is vir Lodenstein die beginpunt van die "heilsweg" en die begin van die afkering van die sonde. ${ }^{25}$ ) Hierdie geloof is iets wat objektief-gegewe is, ${ }^{26}$ ) wat deur die inwerking van die Heilige Gres in die mens tot stand kom. Danksy hierdie geloof ontvang die mens die wil om hom af te keer van die sonde en toe te keer tot God. Daarby is die geloof die moontlikheid ,door welke wy na den styl van 't $\mathrm{H}$. Woord, en de Gereformeerde Leere, doorgaans gesegd werden Christi en aller syner weldaden deelagtig te werden, ende Christus selve in onse herten te woonen ... en die te reynigen.." ${ }^{27}$ ) Die gevolg van die geloof is dat die mens in Christus as geheel volmaak en sonder vlek deur God aangesien word, omdat die mens die geregtigheid van Christus ontvang. So is die geregtigheid van Christus tot regverdiging van die sondaar, maar daarby verklaar Lodenstein met nadruk dat die

21) Geestelyke Gedagten, bls. 279-280.

22) Geestelyke Gedagten, bl. 275.

23) Beschouwinge van Zion, bl. 147.

24) Beschouwinge van Zion, bl. 238.

25) Geestelyke Gedagten, bl. 337.

26) Geestelyke Gedagten, bl. 332.

27) Geestelyke Gedagten, bl. 335. 
mens se werke daardeur nié volmaak word nie. ${ }^{28}$ ) Tog het die goeie 28) Beschouwinge van Zion, bl. 179.

werke op indirekte wyse wel waarde. „Onse Leere is: de Goedewerken zijn van ons niet te doen om daar door te verdienen, maar uyt liefde tot God, uyt eene ingeschapen Heyligheyd, en inwoonende Godheyd, zynde de selve een begin van 't Hemelsch leven . .." ${ }^{29}$ ) In die eerste plek egter is die goeie werke die resultaat van die inwoning ${ }^{30}$ ) van Christus of die Heilige Gees in die mens. God word deur hierdie inwoning egter nie wesenlik een met die mens nie ${ }^{31}$ ) maar ,de twee naturen blijven gescheiden, zóó, dat de daden wel door den $\mathrm{H}$. Geest als eerste, doch door den mensch als tweede en eigenlijke oorzaak geschieden, en de Godheid niet is de inwendige bewerker van der menschen handelingen, maar by dese assisteert." ${ }^{32}$ )

$\mathrm{Na}$ die geloof volg dan die bekering, ,het middel om waarlijk christenen te worden, m.a.w. om tot de selfverlochening te komen." Die bekering en die wedergeboorte is dan twee momente wat saamval en word deur Lodenstein as besonder belangrik aangemerk, selfs so dat hy die eis stel dat die professore aan die Universiteite die teologiese studente daartoe moet "oefen". ${ }^{33}$ ) Die bekering sien Lodenstein as 'n eenmalige gebeurtenis wat nie weer herhaal hoef te word nie en wat byna dieselfde waarde het as die wedergeboorte. Die bekering beskou hy as $n$ bevel van God ${ }^{34}$ ) tot die mens om hom af te keer van sy „onsaligen grond" en om hom in alles te keer tot die soek na God en om homself in eiendom aan God oor te gee. Die bekering en wedergeboorte bly vir Lodenstein met sy piëtisties-methodistiese denke, net stadia op die weg na die heiligmaking, ${ }^{35}$ ) want daar draai alles om.

Die bekeerde mens moet nou deur verdieping in en beskouing van Gods ewigheid, heiligheid, wysheid en ander volmaakthede kom tot die selfverloëning. ${ }^{36}$ ) .,Sal nu de mensche in der daad Gelukzalig zyn, so moet hy dat voorwerp God deelagtig worden . . . . dat sulks niet anders geschiedt/ten principale, als door de Heyligmakinge, Deugdsaamheyt, conformiteit met 's Heeren Wet, of hoe men 't noemen wil welk niet anders is als de ware selfverloochening." ${ }^{37}$ ) Deur die selfverloz̈ning het die mens egter nog nie die ware en volkome volmaaktheid bereik nie, maar slegs 'n begin daarvan. Die volle volmaaktheid kan alleen verkry word deur die oefening. Die onvolmaktheid, na

28) Beschouwinge van Zion, bl. 179.

29) Beschouwinge van Zion, bl. 243.

30) Beschouwinge van Zion, bl. 166

31) Heerlykheid van een Waar christelyk Leven, bl. 13.

32) Proost, A. W., bl. 139.

33) Beschouwinge van Zion, bl. 219.

34) Geestelyke Gedagten, bl, 220.

35) Vergelyk Geestelyke Gedagten, bls. 257-259.

36) Proost, a.w., bl. 139.

37) Beschouwinge van Zion, bl. 144.

38) Beschouwinge van. Zion, bl. 178. 
die bekering, ,is den mensch te vernederen ende uyt hem selve/te dryven tot eenen anderen," ${ }^{38}$ ) dit wil sê, tot God. Daarom moet die mens hom daagliks weer afkeer van die sondige en streef na die volmaaktheid. Hierdie voortdurende toekeer tot God en die afkeer van die onvolmaaktheid, staan vir Lodenstein egter in die kader van die heiligmaking en val nie onder die eenmalige bekering van die mens nie. In sy strewe na die volmaakte het die mens egter die troos om te weet dat hy in beginsel die volmaaktheid reeds besit. ${ }^{39}$ ) Die strewe na volmaaktheid moet gedra word deur die middele daartoe, naamlik die selfverloëning en daarmee samegaande asketisme. ${ }^{t 0}$ ) Lodenstein wys daarop dat die heiligmaking nog nie gelykstaande is aan die verheerliking nie. ${ }^{41}$ ) Die saligheid hier op aarde is egter al te smaak aangesien dit niks anders is as ,onse Vrywillige Onderwerpinge aan den Heere God, als de Souverayne bevelmagt/om hem in tyd/en in eeuwigheid ten dienste te zyn door verlochening van alle eygen, en syne verheerlijkinge". ${ }^{2}$ )

Omdat die mens en dan veral die wedergebore mens by Lodenstein in die middel van die aandag staan, daarom is hy ook 'n voorstander van die piëtistiese konventiekel. Hierdie vergaderinge van bekeerdes en wedergeborenes was in wese eintlik separatisties van aard, hoewel Lodenstein dit self nooit so wil sien nie. Dit dui egter daarop dat vir hom 'n kerk van ware wedergeborenes meer ideaal is as 'n volkskerk. Daarom stel Lodenstein ook die eis dat die kinders van ouers van wie nie met sekerheid uitgemaak kan word dat hulle bekeer is nie. nie gedoop mag word nie. Om dieselfde rede wou hy, in sy laaste lewensjare, nie die sakrament van die Nagmaal bedien nie, omdat hy nie seker kon wees dat hy nie miskien die genademiddels sou gee aan „onkundigen en onheiligen" nie. ${ }^{43}$ )

Die bekeerde en wedergebore mens is vir Lodenstein dié mens wat die volmaaktheid reeds in beginsel ontvang het deur die bekering en nou sy weg moet gaan deur 'n voortskrydende ontsondigingsproses na die geluksaligheid. Die geluksaligheid word dan gesien as die volkome geniet van God met verstand en wil.

By die mens, voor sy bekering, is die verstand die moontlikheid waardeur hy God kan leer ken deur die Heilige Skrif. As die mens egter slegs op homself moet steun in sy soektog na God, sal hy nie verder kom as in historiese of lettergeloof nie, en dit het geen waarde nie. ${ }^{4)}$ Die saligmakende geloof kan die mens egter nie self verwerf

39) Heerlykheid van een Waar christelyk leven, bls. $15 \mathrm{vgg}$.

10) Geestelyke Gedagten, bl. 279.

11) Beschouroinge van Zion, bl. 145.

42) Beschouwinge van Zion, bl. 149.

43) H. VAN RYP, Zions Weelclagen, bl. 9.

11) Beschouvinge van Zion, bl. 25. 
nie. Daarvoor kan hy slegs stilsit en niks doen nie, slegs sug en begeer en homself heeltemal oopstel vir Gods invloed. 'n Mens moet wedergebore wees, maar self kan hy daar niks aan doen nie. Alle menslike aktiwiteit word hier deur Lodenstein uitgeskakel. Die wedergeboorte, die verligting deur die Heilige Gees, is suiwer 'n kwessie van uitverkiesing. Eers met die verligting kom die mens tot die suiwere kennis van die Heilige Skrif en die geloof. Deur die verligting van die verstand, dit wil sê deur die bekering en wedergeboorte, leer die mens God dan ook werklik ken. Na die verligting van die verstand word die wil ook ingeskakel waardeur die mens kom tot die liefkry en liefhê van God. Met dit alles kom die Heilige Gees in die mens woon en word die mens ontsondig, hoewel sy werke nog sondig bly. ${ }^{45}$ )

Hierdie opvattinge van Lodenstein is tipies vir die quiëtistiese piëtisme. ${ }^{46}$ ) Dit is nie net ten opsigte van die bekering dat Lodenstein quiëtisties dink nie, maar hy sien dit as lewenshouding, as VAN RYP geglo mag word as hy sê: „Hierom wilde Lodenstein, dat men gedurig van God moest afhangen/voor zyn voeten leggen/en af-wagte wat de Heere sou believen te doen: en noyt in eygen kragt wat beginnen/ maar alles in de kragt van Jehova/en in name van Jesus." Hirdie uitspraak van VAN RYP en Lodenstein se quiëtistiese denkbeelde kontrasteer met sy meer aktiwistiese uitsprake. Miskien moet hierdie quiëtistiese trek in sy vroomheid verklaar word as samehangend met sy mistieke neigings en die sterk nadruk wat hy plaas op die subjektiewe in die geloof en vroomheid. In die geheel van sy vroomheid staan hierdie quiëtistiese neigings egter seker agter ten opsigte van die meer aktiwistiese.

Lodenstein sien die mens se wil en verstand as die middele waardeur hy tot vereeniging met God kan kom. Dit is interessant dat hy in sy formele beskouings die gevoel heeltemaal tersyde laat, terwyl dit juis in sy vroomheid so ' $n$ rol speel. Hierdie benadrukking van die wil en die verstand, egter, gee Lodenstein se vroomheid 'n bepaalde intellektualistiese kant.

Soos reeds in die voorafgaande aangetoon, is die opdrag wat die bekeerde en wedergebore mens volgens Lodenstein ontvang, om nou deur middel van selfverloëning afstand te doen van die wêreldse en om deur voortdurende oefening en meditasie te trag om die volkome saligheid te bereik, dit wil sê, die onmiddelike geniet van God. Die sondige werke wat die mens bly aankleef, selfs na die wedergeboorte. moet deur die selfverloëning en die stipte navolging van Gods wet, deur die mens self tot ' $n$ absolute minimum gereduseer word.

45) Vergelyk Beschouwinge van Zion, bls. 25-28 en 101.

46) G. C. VAN NifTRIK, Kleine Dogmatiek, Nijkerk, 1953, bl. 346. 
Hier wil ons uitbrei om vas te stel wat Lodenstein verstaan onder die heiligmaking en die innerlike proses van voortskrydende ontsondiging, want met die uiteensetting daarvan kom die trekke van Lodenstein se vroomheid ook sterker na vore. Agtereenvolgens kom dan ter bespreking die afsien van die wêreldse, die selfverloëning en die oefening en meditasie.

Alhoewel Lodenstein 'n man van vermoë was, het hy 'n besonder ingetoë lewe gelei en maar min belangstelling getoon vir die aardse besit. ${ }^{47}$ ) Die genot van die aardse goed verwerp hy heeltemaal en slegs die gebruik van die noodsaaklikste om die lewe te behou om sodoende te kan bestaan tot Gods eer, ag hy verantwoord. Tog gaan dit by hom nooit sover dat hy versaking of ontvlugting van die wêreld leer nie. Sy waardering vir die kloosterlewe lê in die lyn van sy negatiewe houding ten opsigte van die aardse, maar dit hoef nog nie ,eine katholisch gestimmte Frömmigkeit" genoem te word nie. ${ }^{48}$ ) Lodenstein sien die wêreldse meer as 'n bedreiging vir die mens se sieleheil en predik daarom onthouding ten opsigte van die aardse. ${ }^{49}$ ) Die aardse is nie net iets waarvan die mens hom moet onthou nie, maar is eintlik iets wat onbelangrik is ten opsigte van die Goddelike, waarop al sy aandag gevestig was.

Ach! hoe nietig//Hoe verdrietig

Is des Werelds ommegank!

Die met Woorden//Ons vermoorden/

En verstikken met haar stank.

ô Zalig eenzaam! met Godt gemeenzaam!

Duure dat vry Eeuwen lank! ${ }^{\mathbf{s}_{0}}$ )

Lodenstein lê die aksent, in sy vroomheid, op die heiligheid van die mens se lewe en eis dat die mens moet heilig wees voor God. Dit bring mee dat sy belangstelling verskuif van die soewereine God na die mens wat met die hulp van die inwonende God sy stryd teen die wêreld en die vlees voer. Daarom is Lodenstein se beoordeling van die aardsmenslike ook negatief. ${ }^{51}$ ) Waar CaLvyN die vrye gebruik leer van die aardse goedere solank dit strek tot Gods eer, daar staan Lodenstein op die standpunt van 'n asketiese houding ten opsigte van die aardse, en 'n gebruikmaking tot net sover as wat die absoluut-noodsaaklike toelaat. TRIMP verklaar hierdie houding van Lodenstein as volg: „Lodensteyn's denken ligt in de gevoelsfeer van het absolute; en kent niet de symthese van het ,en ... en', doch alleen het antithese van het, of ...

47) Vergelyk Proost, a.w., bl. 28.

18) Beschouwinge van Zion, bl. 211 is in hierdie verband tekenend.

19) W. GoETHERS, Die Vorbereitung des Pietismus in der Reformierten Kirche der Niederlande bis zur Labadistischen Krisis 1670, Leipzig, 1911, S. 117.

so) Uytspanningen, bl. 397.

si) Vergelyk Uytspanningen, bl. 144. 
of.." ${ }^{52}$ ) Daarom kan Lodenstein, met sy swart-wit denke, ook skerp en helder grense trek ten opsigte van die wêreldse. Die besef van Christus se plaasbekledende lyding beteken nie vir Lodenstein dat mens nou weer in die ruimte van Gods genade gestel is en daarom in beginsel die vrye gebruik van die ondermaanse geskenk is nie. Inteendeel, Christus se lyding en offer is juis vir hom die voorbeeld en aansporing tot die asketiese instelling.

By die selfverloëning gaan dit vir Lodenstein daarom dat die mens hom teenoor God geheel en al op die agtergrond moet skuif.. ${ }^{53}$ ) Die mens moet heeltemaal 'n "Niet" word en terwille daarvan moet alle eise van die verstand en wil en die liggaam onderdruk word terwille van die heiligmaking.

Dit is 't Boek van Margriet

Een schoone suyv're Niet.

Die vast haar wil verspild

In wat den Hemel wild.

Die zig haar Lust ontzeyd /

Om d'Algenoegsaamheyd.

En dus is in dit Leven /

In Lusten, en in Wil, by na een Niet gebleven. ${ }^{54}$ )

Die twee hoofkragte van die siel, naamlik die wil en die ver$\checkmark$ and ${ }^{55}$ ) word in die eerste plek in die selfverloëningsproses betrek. Lodenstein stel dat die deug of die Godsalige lewe die eenwording met God is en daartoe moet die natuurlike en verdorwe verstand ${ }^{56}$ ) heeltemal versaak word. Die hele verstand moet daarop gerig word om God te ken of te geniet. „Dat is, zyn verstand sal gelukkig en zalig zyn, als het dat Eeuwige, Oneyndig, Selfwesig, Onbegrypelyk Wezen en desselfs oneyndige eygenschappen. Heyligheyd, Wysheid, Magt, Goedheyd siet en kent, na dien mate als zyn verstand daar van ontvanklyk is." ${ }^{5}$ ) Die mens moet dus sy verstand volkome afhanklik stel van God en heeltemal toewy aan sy diens. Dit beteken niks anders as die stipte navolging van die onfeilbare Goddelike gebod nie; dit is die hoë eis wat aan die verstand van die wedergebore mens gestel word. Met hierdie eis tot stipte wetsbetragting kom die wettiese karakter van Lodenstein se vroomheid na vore. Daarmee hang 'n definitiewe metodistiese trek saam. Dit blyk ook uit die eis tot wilsversaking.

Onder wilsversaking verstaan Lodenstein die dadelike en hartelike begeerte dat God se wil sal geskied onder alle omstandighede, al

52) TRIMP, a.w., bl. 118.

53) Vergelyk Beschouwinge van Zion, bl. 57.

54) Uytspanningen, bl. 337.

55) Geestelyke Gedagten, bl. 263.

56) Geestelyke Gedagten, bl. 265.

57) Geestelyke Gedagten, bl. 263. 
gaan dit ook teen die mens se wil. ${ }^{38}$ ) Die ooreenstemming van die mens se wil met die van God, beteken die bereik van die begin van die saligheid, reeds op hierdie aarde. ${ }^{5 y}$ )

Meer nog as die eis tot diie verloëning van die verstand het die eis tot wilsversaking Lodenstein op die weg van die wetticisme gebring. ${ }^{\text {"O}}$ )

Lodenstein sien die onderwerping en versaking van die mens se verstand en wil egter slegs in die kader van die absolute eis tot totale onderwerping. ${ }^{61}$ ) Hierdie „versterwing" soos Lodenstein die absolute negasie wat aan die wedergeborene as eis gestel word, noem, is netsoos die verloëning van die verstand en die versaking van die wil nie 'n enkelvoudige gebeurtenis nie, maar ' $n$ steeds voortdurende negatiewe houding. .De versterving is in zichzelve niet anders dan een kwytraken of verliezen van de booze lusten zelve ..." ${ }^{62}$ ) Omdat dit ' $n$ proses is waarin die wedergebore mens gewikkel is, 'n stryd teen die liggaamlike en ander luste, sal daar ook vele probleme en moeilikhede mee gepaard gaan. Maar die stryd moet volgehou word deur 'n vaste metode van lewe te volg ,.want de Reformatie op nergens anders dan op de geheele dodinge van het vleesch is aangelegt." ${ }^{63}$ ) Dat dit selfs vir Lodenstein 'n sware eis was, blyk uit sy sug:

Hert-knagend onverzetlijk Nagt-gepeyns

Wat kund gij met een duyster / diep geveyns /

My vangen! Daar gij nogtans in my voed

Dien gloed. ${ }^{64}$ )

Deur egter sober te wees in sy eet en drink, deur 'n besonder kort nagrus, kortom, deur 'n rigoreuse asketisme ten opsigte van sy liggaam, het Lodenstein hierdie stryd volgehou.

Interessant is wat TRIMP in hierdie verband sê, ${ }^{65}$ ) naamlik dat die sistematiese onderdrukking van sy seksuele begeertes vir Lodenstein swaar moes geval het en dat dit, sowel as sy ongehude staat, sy aanrakingsvlak met die gewone lewe, baie verklein het. TRIMP wys dan ook daarop dat Lodenstein eintlik altyd 'n bietjie verleë is met die dinge wat nie direk tot die geestelike sfeer behoort nie. Die onderdrukking van die seksuele begeertes het ook sy uitwerking op Lodenstein se poësie en die onderdrukte erotiek vind, volgens TRIMP, sy gesublimeerde vorm in die .,Jesus-minne". TRIMP suggereer dan dat

58) Vergelyk Beschouroinge van Zion, bls. 77-78.

59) Vergelyk Geestelyke Opwekker, bls. $269 \mathrm{vgg}$.

60) Geestelyke Gedagten, bls. 264 vgg.

-1) Beschouwinge van Zion, bl. 52.

62) Dagelijksche Meditatiën, aangehaal by M. J. A. DE VRIJER, Uren met Lodenstein, Baarn, s.j., bl. 69.

63) Beschouwinge van Zion, bl. 187.

64) Uytspanningen, bl. 30.

65) TRIMP, a.w., bl, 114. 
Lodenstein se mistieke minneliedere aan Jesus, hierin hulle oorsprong vind.

Om die liggaamlike en ander aanvegtings wat die mens vanuit die wêreld bedreig, teen te staan, gee Lodenstein 'n vaste lewensmetode aan ${ }^{66}$ ) Deur 'n stelselmatige oefening sal die gelowige daarin slaag om sy liggaamlike begeertes te onderdruk en ook teenoor die wêreldse afsydig te staan. ${ }^{67}$ )

Onder die oefening verstaan Lodenstein in die eerste plek die onthouding van te veel voedsel en weelde en die navolg van alles wat kan bydra tot die „temming" van die liggaam. ${ }^{68}$ ) Maar daarnaas bestaan ook die geestelike oefening om sin te gee aan die liggaamlike "versterwing". Hierdie geestelike oefening vind plaas in die kader van die konventiekel, die katkisasieklas of die eensame meditasie. Onder die gesamentlike oefening skakel hy die sing van psalms, die lees en bespreek van preke en alles wat tot die stigting van die mens kan lei. Van die konventiekel sê Lodenstein: ,en derhalven diend na yder Gezang yder der leden vryheyd en tijd te hebben, vrymoedig voort te brengen, 't geen de $\mathrm{H}$. Godheyd in 't Zingen hem door den Geeste geopenbaard of doen gevoelen heeft, op dat dit een vrugtbaare oeffeninge zy." ${ }^{69}$ ) Die gesamentlike oefening het dus ten doel om die gees en liefde tot God op te wek en om die wedergeborene aan te spoor tot goeie werke. Daarby moet dit die mens bring tot besinning. tot ondersoek en oordenking van sy gestalte. ${ }^{70}$ )

Hierdie oordenking dien daartoe dat die mens vir homself kan vasstel of hy werklik wedergebore is en indien wel, hoe die heiligmaking van sy lewe vorder. Juis by hierdie konventiekel-samekomste, wat die uitlewing van die.Piëtisme genoem kan word, val die nadruk baie sterk op die mens en nie meer op God nie. In plaas daarvan dat God sentraal staan en daar teologie bedryf word, word die vrugbaarheid van die samekoms gemeet aan die vraag of die mens gestig is. Dit gaan nie om die hoor en verkondig van die Woord in die eerste plek nie, maar om die subjektiewe belewenisse van die bekeerde mens. Dit is juis op hierdie punt waar Lodenstein en die Piëtisme van die reformatoriese denke afwyk.

Afgesien van die konventiekel-samekomste, moet die mens hom ook daagliks oefen in die vroomheid. Daarvoor gee Lodenstein 'n vaste rooster waarvolgens op gesette tye van die dag die oefening van die devote lewe op die voorgrond kom. ${ }^{11}$ ) Juis terwille van hierdie

66) Dagelijkschse Meditatiën, aangehaal by DE VRIJER, a.w., bl. 70 .

67) Beschouwinge van Zion, bl. 243.

68) Beschowinge van Zion, bl. 211.

69) Voorrede tot die Uytspanningen.

70) Beschouwinge van Zion, bl. 228.

i) Vergelyk Proost, a.w., bl. 140. 
geestelike oefening van die gelowige betreur Lodenstein dit dat die Reformasie die bieg afgeskaf het. $\mathrm{Hy}$ is dan ook ten gunste daarvan om die bieg weer in te voer om as hulp tot die heiligmaking van die mens te dien. ${ }^{12}$ ) Met hierdie uiteensetting blyk ook die metodistiese tendense van die vroomheid van Lodenstein. Die hele gedagte dat die heiligmaking 'n voortgaande ontsondigingsproses is, neig Lodenstein al na die kant van die metodistiese. Dit wys ook dat Lodenstein in sy vroomheid tog nie meer suiwer reformatories is nie.

'n Groot plek in Lodenstein se vroomheid word gevul deur die soek na die eensaamheid om met God te verkeer, die meditasie.
Hier en komen // Geen Onvroomen
Hier en komt geen Vroome by.
Groot nog kleene: Maar alleene
Ik / en Heere Jesu, Gy.
ô Zalig eensaam! Met Godt gemeenzaam!
Daar ik vrolijk ben / en vry.

Vir die mens bestaan hierdie verkeer met die Oneindige in die. totale afsluiting van al die wêreldse om hom sodoende alleen met God besig te hou. Dit kan tot stand gebring word deur die lees van die Bybel, gebed of meditasie. ${ }^{74}$ ) Hierdie persoonlike ervaring van die werklikheid van God moet volgens Lodenstein nie aan toevallige oomblikke van die dag oorgelaat word nie, maar dit moet op gesette tye geoefen word. Vandaar dat hy weer graag vaste- en bededae wil invoer.

Die eensame meditasie loop by Lodenstein egter in die mistiek uit. "Steeds was hy in hooge contemplatien: hy wist door hoge speculatiën alle Goddelyke waarheden tot dese eerste en 't grootste te brengen; God het al, het schepsel niet met al. Dit was het Centrum tot welke hy alle liniën van de gansche circumferentie der Christelyke Religie bragte ... Hoe rymde, hoe zong hy van het gelukkig schipbreuk lijden in de Oneindig Oceaan van Jehova." ${ }^{75}$ ) Ondanks die groot afstand wat Lodenstein sien tussen die Skepper-God en die geskape mens, hou hy tog die gedagte vas dat daar 'n moontlikheid vir die mens is om vanuit homself een te word met God, ,een geheel verliezen .... . van sigselve in de grondloose Oceaan van de Onbegrypelyke Eeuwigheid." ${ }^{76}$ ) Omdat die mistiek egter nie die oorheersende is in sy vroomheid nie, kan Lodenstein naas die begeerte om te ver-

72) Vergelyk Beschouwinge van Zion, bls. 137 en 228.

73) Uytspanningen, bl. 397.

i4) Dagelijksche Meditatiën, aangehaal by DE VRIJER, a.w., bl. 67: Het zoude ongetwyfeld onze bewogenheid over het leyden van onze Zaligmaker zeer stuwen, zoo wij ons er aan gewenden de wonderlijkheid . . dikwels te overpeinzen en door eenzame meditatie op de ziel te binden.

75) H. VAN RYP, Zions Weeklagen, bl. 5.

76) Geestelyke Gedagten, bl. 265. 
sink in die Goddelike ook nog die soewereine persoonlikheid van God bly handhaaf in sy denke ${ }^{77}$ ) Want, ondanks sy mistiek en quiëtisme, bly vir Lodenstein die oorheersende die getroue pligsvervulling in die diens van God. ${ }^{78}$ ) Die mistiek is wel by Lodenstein aanwesig, maar is seker nie die dominerende in sy vroomheid nie. Daarby is dit waarskynlik foutief om met ProOST ${ }^{79}$ ) 'n pantiestiese kleur te gaan onderken in sy vroomheid en mistiek. Daarvoor is Lodenstein tog weer te veel verbonde aan die Calvinisme en staan hy te sterk teenoor die aardse.

Sonder om te wil ingaan op die oorspronge van die vroomheid van Lodenstein, moet tog vasgestel word dat die misticisme wat ons by Lodenstein aantref ' $n$ sekere verband hou met die middeleeuse mistiek. NiEbuHr maak 'n omvattende stelling as hy sê: .,An unbroken line runs from the mediaeval mystics to the Protestant Pietists". ${ }^{80}$ ) Maar dit is miskien te skerp gestel. Proost wys immers daarop dat Lodenstein in sy misticisme die eis stel dat dit heeltemal moet ooreenstem met die leer van die Hervormde Kerk, ${ }^{81}$ ) alhoewel bygesê moet word dat Lodenstein self nie daarin slaag nie. Lodenstein roep egter wel herinneringe op van middeleeuse mistiek. ,This is a pattern, basically, of subsequent mystical ascents to God, whether they be the 'ways' of Bonaventura, the 'twelve degrees of humility and pride' of St. Bernard, or the 'dark night of the soul' of St. John of the Cross. These duplicate, each in its own idiom, the total interest of the medieval world view, which was a system of appetition grounded erotically upon the notion of methaphysical ascent to God. From the standpoint of works, there was ascent by way of the ladder of merit, ... from the standpoint of the inner-life, there was the mystical ascent to God. By these several means the problem of sin as a moral disjunction between God ana' man made actual by an act of defiance and disobedience, was effectively sublimated into a metaphysical problem. It was solved by the purgation of the soul from its attachment to the works of sense, and through concentration on the transcendental essence of the Godhead." ${ }^{82}$ )

Daarby moet onthou word dat Lodenstein, danksy ook sy vriendskap met De Labadie, self die werke van Tauler en Thomas a KeMPIS ken ${ }^{83}$ ) Waarskynlik moet die mistieke element van Lodenstein se vroomheid in verband gebring word met die sterk affektiewe sy van

77) DE VRIJER, a.w., bl. 23.

78) TRIMP, a.w., bls. 27 en 29.

79) Proost, a.20., bl. 145.

80) R. NIEBUHR, The Nature and Destiny of Man, Vol. II, Londen, 1944, p. 144.

81) Proost, a.w., bls. 144-145.

a2) S. R. HOPPER, The Crisis of Faith, New York, s.j., p. 271.

83) Vergelyk Proost, a.w., bl. 144. 
sy karakter. Sy vroomheid dra, veral in sy minneliedere tot Jesus, ${ }^{84}$ ) 'n sterk innig-affektiewe trek. Hierdie trek in Lodenstein se vroomheid, wat 'n sekere teenspraak vorm met die meer intellektualistiese trekke in sy vroomheid, kom sterk na vore in sy beskouing van die Nagmaal: ,dat de Heere Jesus selve sig aan ons geeft, in ons woonen komt, en met ons, eygentlyk te spreken, vereenigt werd, werdende selve de waaragtige en eygentlyke spijse van de zielen." ${ }^{85}$ ) In die lyn van sy benadrukking van die subjektiewe moet ook Lodenstein se sterk afwysing van die ",lettergeloof" gesien word. „Och! wy moesten meer leeren de letter-kennis van liefde te onderscheiden / ende ' $t$ geene uit gebrek van 't eerste en 't geene uit gebrek van 't tweede voortkomt." ${ }^{86}$ ) Die vroomheid is so vir Lodenstein saak van die hart en nie van die verstand nie. TRIMp wys daarop dat Lodenstein se sterk instelling op die geestelike, ten uitsluiting van die ander, meebring dat hy die aardse nie meer as 'n konkrete gegewenheid sien nie, maar as iets wat heeltemal los staan van die geestelike lewe en eintlik parallel daaraan verloop. "Voor de piëtist blijkt egter elken voorval hoe onbeduidend het moge zijn, waarde te hebben, indien het slechts op enigerlei wijze samenhangt met het teer gekoesterde ,bevindelijke' leven." ${ }^{87}$ )

Die innig-affektiewe en mistieke element van Lodenstein se vroomheid beweeg aan die rand van die reformatoriese teologie. Hoewel Lodenstein niks anders as orthodoks wil wees nie, kom hy egter in sy subjektiwisme op die grenslyn, juis omdat hy so sterk na die vereniging van die bekeerde mens met God begeer. Die oorsaak van hierdie kant van Lodenstein se vroomheid kan gesoek word in sy sug na die perfeksionisme, die volmaakte heilig-wees, en sy mindere belangstelling vir die regverdiging van die sondaar. Dit alles bring mee dat die mens in die middelpunt van die aandag van Lodenstein te staan kom. "Sectarian perfectionism is constantly in peril of destroying the paradox of sanctification and justification in Biblical religion. Its experience of grace is conceived entirely as 'Christus in nobis' and not as 'Christus pro nobis'." ${ }^{89}$ ) Tog moet die subjektiewe beklemtoning van die vroomheid deur Lodenstein nie reglynig veroordeel word nie. Dit was tot op sekere hoogte natuurlik 'n reaksie teen die uiterlike intellektualisme van die heersende dogmatisme en juis deur die aandag te vestig op die feit dat die gevoel nie in die godsdiens verwaarloos mag word nie, het Lodenstein in sy eie en later tyd. waarde gehad.

Die gevolg egter van die swaar nadruk wat Lodenstein op die volkome navolging van Gods gebod en die onbereikbare hoë ideaal

84) Uytspanningen, bls. $401 \mathrm{vgg}$.

86) Beschouwinge van Zion, bl. 283.

87) TRIMP, a.w., bls. 17 en 50.

89) NIEBUHR, l.c., p. 177. 
van die heiligheid lê, is dat daar 'n bepaalde somberheid oor sy vroomheid lê.

Dat staad'ge Traanen-vloeden

Door Spijs en Drank mij voeden!

Dat Traanen 's Daags mijn lust zijn /

Dat Traanen 't Nagts mijn rust zijn!

Want ziet! mijn rust en lusteloosheyd is nu mijn lust.

Zwom' maar mijn Bedd' in 'Traan!

Want slapeloos gaan

Dat is al mijn rust ${ }^{90}$ )

Opmerklik is dat wanneer hy die regverdiging van die sondaar besing, daar dan 'n opmerklik vreugdetoon deur sy lied klink. ${ }^{11}$ ) Maar by Lodenstein speel die reformatoriese gedagte van die kindskap van die mens by God, maar 'n geringe rol. Die hele mens se doen en later staan onder die sware eis van die byna onbereikbare heiligmaking. Daarom is die mens wat sug na die volmaaktheid en wat met onrus na sy eie sondigheid kyk met die oortuiging dat hy dit self moet verbeter, meer die tipiese Lodenstein as die mens wie se lewe gedra word deur die vreugdevolle wete dat hy ondanks sy sonde as Gods kind aangeneem is. Tiperend vir Lodenstein is die beskrywing van VAN RYP: „Als een ander vraagde / hoe het met zijn Ziele-staat was? zeide hy / Ik ben arm, blind, en naakt, ja een doode hond ..." ${ }^{92}$ ) Innerlike onvoldaanheid en uiterlike miskenning was die gevolg van die vroomheid van Lodenstein. ${ }^{93}$ )

Tog is die nou weg van pligsgetroue navolging van Gods gebod vir Lodenstein reeds die beginpunt van die heerlikheid. Want tussen die volmaakte heiligheid en die heerlikheid is daar geen wesenlike verskil nie, $\left.{ }^{94}\right)$,en als de regterhand en voet, die ons ergert, was afgekapt, en regter oog van eigen lusten was uitgestoken / dat dan den weg van heiligheit / wyd genoeg zijn zoude/" 95)

90) Uytspanningen, bl. 388 .

91) Uytspanningen, bl. 178.

92) VAN RYP, Zions Weeklagen, bl. 12.

93) TRIMP, a.w., bl. 123.

94) VAN RYP, Zions Weeklagen, bl. 12.

95) H. VAN RYP, Zions Weeklagen, bl. 13 
Lodenstein se vroomheid kan miskien die beste uitgedruk word deur een van die verse van die "Zwanen-Gezang" wat hy op sy sterfbed geskryf het:

Daar hy zig zelf verliezen moet /

En al zijn Heyl / zijn hoogste goed

Moet vinden in.'t verliezen:

't Verliezen van zig zelfs in Godt /

Dat is ons deel ons hoogste lot /

Van ons op 't hoogst te kiezen.

Dat steyl.// Is 't Heyl

Dat gekomen / voor de Vroomen

Is beneden /

En Godts kind'ren stelt in vreeden. ${ }^{96}$ )

A. D. Pont. 